SANTIAGO-LUNA, EG; CARRILLO-RODRIGUEZ, JC; CHÁVEZ-SERVIA, JL; PERALES-SEGOVIA, C; HEREDIA-GARCIA, E. 2018. Variation of plant and fruit traits in native Mexican costeño pepper. HorticulturaBrasileira 36: 399-407. DOI - http://dx.doi.org/10.1590/S0102-053620180319

\title{
Variation of plant and fruit traits in native Mexican costeño pepper
}

\author{
Eric G Santiago-Luna ${ }^{1}$; José C Carrillo-Rodríguez'; José L Chávez-Servia² ${ }^{2}$ Catarino Perales-Segovia ${ }^{3}$; \\ Elena Heredia-Garcia ${ }^{4}$
}

${ }^{1}$ Instituto Tecnológico del Valle de Oaxaca, Oaxaca, México; jcarrillo_rodriguez@hotmail.com (correspondence author); ${ }^{2}$ Instituto Politécnico Nacional, Oaxaca, México; ${ }^{3}$ Instituto Tecnológico El Llano Aguascalientes, Aguascalientes, México; ${ }^{4}$ Instituto Nacional de Investigaciones Forestales, Agrícolas y Pecuarias, Guanajuato, México

\begin{abstract}
In a collection of costeño peppers conserved by indigenous producers from the municipalities of Santa Maria Tonameca and Santo Domingo de Morelos, Oaxaca, Mexico, a description and classification of agromorphological variation was undertaken by characterization of 46 populations in a greenhouse distributed under complete randomized block design with three replicates. Days to first flowering, plant and fruit traits and yield per plant were evaluated. Significant differences were detected for all traits except for plant height at 120 days after planting. In a principal component analysis, the variables of green and dry weight of 15 fruits, average fruit weight, number of fruits and yield per plant were the characteristics with major descriptive value for the total phenotypic variance. In addition, two patterns of agromorphological variation were determined; for productivity, one was highly variable and integrated with pepper populations from La Oscurana, Villa Unión and San Juanito communities, and the other was integrated with less variable populations, such as those from Las Pilas. These phenotypic patterns were confirmed in a cluster analysis, where five phenotypic groups were statistically significantly different. Complementarily, an inverse relationship was determined between number of fruits per plant and average fruit weight in ten populations that presented high agronomic potential; a yield greater than $500 \mathrm{~g}$ per plant, more than 100 fruits per plant and an average weight greater than $3.9 \mathrm{~g}$ per fruit were detected.
\end{abstract}

Keywords: Capsicum annuum, phenotypic diversity, plant genetic resources, characterization, multivariate analysis.

\begin{abstract}
RESUMO
Variação de características de plantas e frutos em pimenta mexicana costeira nativa

Em uma coleção de pimentas mexicana costeira nativa, conservada por produtores indígenas dos municípios de Santa Maria Tonameca e Santo Domingo de Morelos, México, descreveu e classificou-se a variação agromorfológica, a partir de uma coleção de 46 populações caracterizadas em casa de vegetação, em delineamento de blocos completos ao acaso com três repetições. Foram avaliados os dias do transplante até a primeira floração, caracteres da planta, fruto e rendimento por planta. $\mathrm{Na}$ análise de variância foram determinadas as diferenças significativas entre populações em todos caracteres avaliados, exceto na altura da planta aos 120 dias após o transplante. $\mathrm{Na}$ análise dos componentes principais determinamos que as variáveis de maior valor descritivo foram peso fresco e seco de 15 frutos, peso médio do fruto, número de frutos por planta e rendimento por planta. Também se observaram dois padrões gerais de variabilidade agromorfológica; um composto por populações altamente variáveis, originárias das comunidades de La Oscurana, Villa Unión e San Juanito, e outro menos disperso de Las Pilas, que indica divergência entre as comunidades de origem. Ambos padrões se refletiram na análise de conglomerados mediante a integração de cinco grupos fenotípicos estatisticamente divergentes.Se observou uma relação inversa entre número de frutos por planta e peso médio de frutos. Adicionalmente, se identificou um potencial agronômico em dez populações de pimenta costeira, com rendimentos por planta superiores a $500 \mathrm{~g}$ e mais de 100 frutos por planta com uma densidade média maior que $3,9 \mathrm{~g}$ por fruto.
\end{abstract}

Palavras-chave: Capsicum annuum, diversidade fenotípica, recursos genéticos vegetais, caracterização, análise multivariada.

Received on September 27, 2017; accepted on August 28, 2018

$\mathrm{P}$ eople in Mexico have collected or cultivated and consumed peppers (Capsicum spp.) for hundreds of years, preserving a high diversity of wild and domesticated forms in situ in traditional agrosystems and in protected and unprotected reserves (AguilarMeléndez et al., 2009; Kraft et al., 2014; Narez-Jiménez et al., 2014).
Farmers play an important role in the communities by selecting and preserving this cultivated diversity; they distinguish each intraspecific variation or species by flavor, aroma, color, and pungency, among other characteristics, being direct consumers of the diversity by preparing a great variety of dishes of Mexican gastronomy (Cazares et al.,
2005). As a result, farmers distinguish local varieties by fruit, plant, and time from sowing or transplanting to fruiting as well as by sensory aspects, reflecting part of the high biogeographic and socio-cultural heterogeneity of origin of that diversity (Votava et al., 2005; Castellón-Martínez et al., 2012, 2014).

Each study of genetic or phenotypic 
diversity of Capsicum reflects part of the genetic structure of populations and their phenotypic responses to environmental variations; this information applies to planning strategies for conservation, recovery, and use of the genetic diversity of Capsicum. Some examples include documenting the genetic and phenotypic diversity of Capsicum in Spain (Rivera et al., 2016); morphological characterization of Capsicum in Turkey (Kadri et al., 2009); variation of agronomic and morphological traits of C. baccatum and C. annuum in Argentina (Occhiuto et al., 2014); agro-morphological variations of $C$. frutescens in Tunisia (Zhani et al., 2015); phenotypic diversity of C. baccatum in Brazil (Rêgo et al., 2011); and domestication studies and pre-Hispanic and modern geographic distribution in Mexico (Aguilar-Rincón et al., 2010; Kraft et al., 2014). Aspects of local seed exchange systems, fruit selection criteria, and adaptations to agro-ecosystems or specific agroecological microniches have also been documented in indigenous community territories (Portis et al., 2004; Boege, 2008; Kraft et al., 2010).

China, Mexico, Turkey, Spain, Indonesia, the United States, and Egypt are the main producers of Capsicum spp., accounting for $75 \%$ of world production. Mexico is the main exporter for fresh consumption (vegetables), having produced 2.7 million tons of fresh peppers and 98,000 tons of dried peppers in 2015. The annual consumption per capita varies between 15 and $16 \mathrm{~kg}$ of some fruit varieties, known as Bell, Serrano, Jalapeño, and Habanero. However, up to 100 regional types are grown, occupying over 100 thousand hectares per annum. Some of the best known regional varieties in Mexico are Ancho, Mirasol, Poblano, Chilaca, Guajillo, Tabaquero, Colorado, Pasilla, Puya, Árbol or Cola de Rata, Costeño, and Piquín, among others. The costeño pepper of the Coast of Oaxaca is in high demand for preparing different moles, sauces, or regional dishes (Ovando, 2007) and for its annual production of 800 tons of dried yellow and red chili in family agriculture (SIAP, 2015). This way of naming Capsicum types is common among farmers and aims to identify a specific phenotypic variation or local variety. This is also common in Peru and Bolivia (Van Zonneveld et al., 2015) and represents the variety of gene pools preserved by farmers. Further, the fixation of specific traits results from differential responses to biotic and abiotic stress conditions, crop management, and selection pressures imposed by farmer (Kraft et al., 2010; Portis et al., 2004).

In situ preservation of the genetic diversity of $C$. annum in its center of origin, domestication, and diversification, facilitates the study of high levels of genetic diversity in small geographical spaces, which harbor diverse indigenous groups and high biocultural diversity (Boege, 2008). In those biocultural regions, for example, Worthington et al. (2012) and Soleri et al. (2013) demonstrated the presence of high levels of inter- and intraspecific genetic diversity of Phaseolus in an indigenous community of Oaxaca, Mexico. In the case of Capsicum, selecting for fruit shape and local seed exchange are key aspects of preserving specific phenotypic variations (Kraft et al., 2010). However, it is first necessary to describe the phenotypic variations of local or regional interest based on agronomic potential or fruit quality, which can be used in a breeding program. This study aims to evaluate agro-morphological variability of a collection of native populations of costeño pepper (Capsicum annuum) of the Coast of Oaxaca, Mexico, based on agro-morphological plant and fruit traits. This information is necessary to plan conservation and use strategies.

\section{MATERIAL AND METHODS}

Germplasm accession by farmers in Oaxaca, Mexico

Based on previous records of distribution of Capsicum throughout the coast of Oaxaca, an accession of cultivated populations of costeño pepper was collected from November to December 2012 in twelve communities of the municipalities of Santa María Tonameca and Santo Domingo de
Morelos (15'46'35.9" to $15^{\circ} 51^{\prime} 16.6^{\prime}$ 'N, $96^{\circ} 39^{\prime} 19.6^{\prime \prime}$ to $96^{\circ} 47^{\prime} 2.1^{\prime \prime} \mathrm{W}$, altitude 84 to $255 \mathrm{~m}$ ), totaling 46 populations (one sample per community) donated by farmers (Table 1). Annual temperature varies from 23.2 to $31.7^{\circ} \mathrm{C}$, annual precipitation of $641 \mathrm{~mm}$, and a warm sub-humid climate (INIFAP, 2012).

Experiment and morphological characterization

The accession collection of chili pepper populations was sown on April 26, 2013, in commercial peat moss (Sphagnum sp.) substrate; 30 days after sowing seedlings were transplanted to a greenhouse at Technological Institute of the Valley of Oaxaca $\left(17^{\circ} 011^{\prime} 10.42\right.$ 'N, $96^{\circ} 45^{\prime} 52.32^{\prime}$ 'W, altitude $1561 \mathrm{~m}$ ), with mean environmental temperature of $21.1^{\circ} \mathrm{C}$. The transplant beds included a mixture of soil, pinus sawdust, chopped cabbage (Brassica sp.), and cattle organic matter, plus background fertilization with $0.5 \mathrm{~kg}$ of $00: 18: 46$ NPK per $30 \mathrm{~m}$ bed, covering them with plastic netting. Daily drip irrigation was applied, with calcium nitrate, magnesium nitrate, and 18:18:18 NPK added twice a week. In addition, a pest and disease control program was carried out with different entomopathogenic fungi and fungicides.

In order to evaluate the environmental effect such as temperature and altitude under evaluation conditions on flower and fruit production, developmental and yield-related variables were used to characterize and evaluate the populations of chili pepper. Plant height $(\mathrm{cm})$ was measured at 60 and 120 days after transplanting (DAT), at flowering, and at harvest. For harvest measurements, five fruits, unless otherwise specified, were used to measure dimensions and weight based on the proposal of Silva et al. (2011). Measurements at harvest (when color changed from green to red) included number of fruits per plant, weight $(\mathrm{g})$, fruit length $(\mathrm{cm})$ and width $(\mathrm{cm})$, yield per plant $(\mathrm{g})$, fresh and dry weight $(\mathrm{g})$ of 15 fruits of a cutting or harvest ( 30 days at room temperature, 20 to $30^{\circ} \mathrm{C}$ and $30-45 \%$ relative humidity in the laboratory), average fruit weight (g), and average fruit yield per plant, based on studies by Occhiuto et al. (2014), Castellón-Martínez et al. (2014), and 
Table 1. List of the populations of costeño pepper characterized and evaluated, provided by different farmers of Santa María Tonameca and Santo Domingo de Morelos, Oaxaca, Mexico. Mexico, Instituto Tecnológico del Valle de Oaxaca, 2013.

\begin{tabular}{|c|c|c|c|c|}
\hline Population (ID) & Location and municipality & Altitude (m) & Latitude $\mathbf{N}$ & Longitude $\mathbf{O}$ \\
\hline$\overline{\mathrm{CCO} 01}$ & La oscurana, Sta. M. Tonameca & 100 & $15^{\circ} 47^{\prime} 34.7^{\prime \prime}$ & $96^{\circ} 46^{\prime} 18.6^{\prime \prime}$ \\
\hline $\mathrm{CCO} 02$ & Piedra Mujer, Sta. M. Tonameca & 139 & $15^{\circ} 48^{\prime} 15.6^{\prime \prime}$ & $96^{\circ} 45^{\prime} 47.9^{\prime \prime}$ \\
\hline $\mathrm{CCO} 03$ & Barrio Nuevo, Sto. Domingo de Morelos & 164 & $15^{\circ} 49^{\prime} 56.3^{\prime \prime}$ & $96^{\circ} 39^{\prime} 19.6^{\prime \prime}$ \\
\hline $\mathrm{CCO} 04$ & San Bernardino, Sta. M. Tonameca & 89 & $15^{\circ} 47^{\prime} 19.4^{\prime \prime}$ & $96^{\circ} 48^{\prime} 37.4 ”$ \\
\hline $\mathrm{CCO} 05$ & San Bernardino, Sta. M. Tonameca & 84 & $15^{\circ} 47^{\prime} 34.0^{\prime \prime}$ & $96^{\circ} 48^{\prime} 55.0^{\prime \prime}$ \\
\hline $\mathrm{CCO} 06$ & San Juanito, Sta. M. Tonameca & 97 & $15^{\circ} 47^{\prime} 25.1^{\prime \prime}$ & $96^{\circ} 47^{\prime} 19.6^{\prime \prime}$ \\
\hline $\mathrm{CCO} 07$ & San Juanito, Sta. M. Tonameca & 100 & $15^{\circ} 47^{\prime} 26.3^{\prime \prime}$ & $96^{\circ} 47^{\prime} 18.4^{\prime \prime}$ \\
\hline $\mathrm{CCO} 08$ & San Juanito, Sta. M. Tonameca & 94 & $15^{\circ} 47^{\prime} 28.8^{\prime \prime}$ & $96^{\circ} 46^{\prime} 58.5^{\prime \prime}$ \\
\hline $\mathrm{CCO} 10$ & San Juanito, Sta. M. Tonameca & 99 & $15^{\circ} 47^{\prime} 21.6^{\prime \prime}$ & $96^{\circ} 47^{\prime} 01.2^{\prime \prime}$ \\
\hline CCO11 & San Juanito, Sta. M. Tonameca & 99 & $15^{\circ} 47^{\prime} 21.6^{\prime \prime}$ & $96^{\circ} 47^{\prime} 01.2 ”$ \\
\hline $\mathrm{CCO} 12$ & El Zapote, Sta. M. Tonameca & 127 & $15^{\circ} 48^{\prime} 01.8^{\prime \prime}$ & $96^{\circ} 46^{\prime} 14.0 "$ \\
\hline $\mathrm{CCO} 13$ & El Zapote, Sta. M. Tonameca & 126 & $15^{\circ} 48^{\prime} 01.7^{\prime \prime}$ & $96^{\circ} 46^{\prime} 13.3^{\prime \prime}$ \\
\hline $\mathrm{CCO} 14$ & La Oscurana, Sta. M. Tonameca & 100 & $15^{\circ} 47^{\prime} 33.9^{\prime \prime}$ & $96^{\circ} 46^{\prime} 17.6^{\prime \prime}$ \\
\hline $\mathrm{CCO} 15$ & La Oscurana, Sta. M. Tonameca & 98 & $15^{\circ} 47^{\prime} 32.6^{\prime \prime}$ & $96^{\circ} 46^{\prime} 18.8^{\prime \prime}$ \\
\hline $\mathrm{CCO} 16$ & La Oscurana, Sta. M. Tonameca & 100 & $15^{\circ} 47^{\prime} 34.6^{\prime \prime}$ & $96^{\circ} 46^{\prime} 18.8^{\prime \prime}$ \\
\hline $\mathrm{CCO} 17$ & La Oscurana, Sta. M. Tonameca & 91 & $15^{\circ} 47^{\prime} 23.6^{\prime \prime}$ & $96^{\circ} 46^{\prime} 34.5^{\prime \prime}$ \\
\hline $\mathrm{CCO} 18$ & La Oscurana, Sta. M. Tonameca & 91 & $15^{\circ} 47^{\prime} 22.3^{\prime \prime}$ & $96^{\circ} 46^{\prime} 32.6^{\prime \prime}$ \\
\hline CCO19 & La Oscurana, Sta. M. Tonameca & 98 & $15^{\circ} 47^{\prime} 32.0^{\prime \prime}$ & $96^{\circ} 46^{\prime} 23.7^{\prime \prime}$ \\
\hline $\mathrm{CCO} 20$ & La Oscurana, Sta. M. Tonameca & 97 & $15^{\circ} 47^{\prime} 30.4^{\prime \prime}$ & $96^{\circ} 46^{\prime} 24.4 "$ \\
\hline $\mathrm{CCO} 21$ & La Oscurana, Sta. M. Tonameca & 97 & $15^{\circ} 47^{\prime} 30.9^{\prime \prime}$ & $96^{\circ} 46^{\prime} 23.8^{\prime \prime}$ \\
\hline $\mathrm{CCO} 22$ & La Oscurana, Sta. M. Tonameca & 96 & $15^{\circ} 47^{\prime} 31.3^{\prime \prime}$ & $96^{\circ} 46^{\prime} 20.9 \prime$ \\
\hline $\mathrm{CCO} 23$ & La Oscurana, Sta. M. Tonameca & 96 & $15^{\circ} 47^{\prime} 31.6^{\prime \prime}$ & $96^{\circ} 46^{\prime} 21.1 ”$ \\
\hline $\mathrm{CCO} 24$ & La Oscurana, Sta. M. Tonameca & 97 & $15^{\circ} 47^{\prime} 32.2^{\prime \prime}$ & $96^{\circ} 46^{\prime} 20.2^{\prime \prime}$ \\
\hline $\mathrm{CCO} 25$ & La Oscurana, Sta. M. Tonameca & 101 & $15^{\circ} 47^{\prime} 34.6^{\prime \prime}$ & $96^{\circ} 46^{\prime} 14.9 \prime$ \\
\hline $\mathrm{CCO} 26$ & Palma Larga, Sta. M. Tonameca & 139 & $15^{\circ} 48^{\prime} 09.1^{\prime \prime}$ & $96^{\circ} 45^{\prime} 31.3 ”$ \\
\hline $\mathrm{CCO} 27$ & Palma Larga, Sta. M. Tonameca & 142 & $15^{\circ} 48^{\prime} 10.0^{\prime \prime}$ & $96^{\circ} 45^{\prime} 30.9^{\prime \prime}$ \\
\hline $\mathrm{CCO} 28$ & Villa Unión, Sta. M. Tonameca & 128 & $15^{\circ} 48^{\prime} 20.0^{\prime \prime}$ & $96^{\circ} 44^{\prime} 39.1 "$ \\
\hline $\mathrm{CCO} 29$ & Barranca Honda, Sta. M. Tonameca & 174 & $15^{\circ} 47^{\prime} 03.5^{\prime \prime}$ & $96^{\circ} 40^{\prime} 35.6^{\prime \prime}$ \\
\hline $\mathrm{CCO} 30$ & Barranca Honda, Sta. M. Tonameca & 175 & $15^{\circ} 47^{\prime} 04.8^{\prime \prime}$ & $96^{\circ} 40^{\prime} 37.2 ”$ \\
\hline $\mathrm{CCO} 31$ & Charco de Agua, Sta. M. Tonameca & 99 & $15^{\circ} 46^{\prime} 35.9^{\prime \prime}$ & $96^{\circ} 40^{\prime} 02.6^{\prime \prime}$ \\
\hline $\mathrm{CCO} 32$ & Las Pilas, Sta. M. Tonameca & 180 & $15^{\circ} 50^{\prime} 32.7^{\prime \prime}$ & $96^{\circ} 43^{\prime} 56.8^{\prime \prime}$ \\
\hline $\mathrm{CCO} 33$ & Las Pilas, Sta. M. Tonameca & 187 & $15^{\circ} 50^{\prime} 46.8^{\prime \prime}$ & $96^{\circ} 43^{\prime} 36.8^{\prime \prime}$ \\
\hline $\mathrm{CCO} 34$ & Las Pilas, Sta. M. Tonameca & 188 & $15^{\circ} 50^{\prime} 46.5^{\prime \prime}$ & $96^{\circ} 43^{\prime} 37.8^{\prime \prime}$ \\
\hline $\mathrm{CCO} 35$ & Las Pilas, Sta. M. Tonameca & 245 & $15^{\circ} 51^{\prime} 14.2^{\prime \prime}$ & $96^{\circ} 51^{\prime} 14.2 "$ \\
\hline $\mathrm{CCO} 36$ & Las Pilas, Sta. M. Tonameca & 245 & $15^{\circ} 51^{\prime} 14.3^{\prime \prime}$ & $96^{\circ} 43^{\prime} 17.9 "$ \\
\hline $\mathrm{CCO} 37$ & Las Pilas, Sta. M. Tonameca & 190 & $15^{\circ} 50^{\prime} 46.3^{\prime \prime}$ & $96^{\circ} 43^{\prime} 40.8^{\prime \prime}$ \\
\hline $\mathrm{CCO} 38$ & Las Pilas, Sta. M. Tonameca & 192 & $15^{\circ} 50^{\prime} 47.3^{\prime \prime}$ & $96^{\circ} 43^{\prime} 40.1 "$ \\
\hline CCO39 & Las Pilas, Sta. M. Tonameca & 192 & $15^{\circ} 50^{\prime} 47.3^{\prime \prime}$ & $96^{\circ} 43^{\prime} 40.1 ”$ \\
\hline $\mathrm{CCO} 40$ & Las Pilas, Sta. M. Tonameca & 255 & $15^{\circ} 51^{\prime} 16.6^{\prime \prime}$ & $96^{\circ} 43^{\prime} 18.1 ”$ \\
\hline $\mathrm{CCO} 41$ & El Zapote, Sta. M. Tonameca & 126 & $15^{\circ} 48^{\prime} 03.4^{\prime \prime}$ & $96^{\circ} 46^{\prime} 13.4^{\prime \prime}$ \\
\hline $\mathrm{CCO} 42$ & La Oscurana, Sta. M. Tonameca & 107 & $15^{\circ} 47^{\prime} 44.4^{\prime \prime}$ & $96^{\circ} 46^{\prime} 00.9^{\prime \prime}$ \\
\hline $\mathrm{CCO} 43$ & Villa Unión, Sta. M. Tonameca & 128 & $15^{\circ} 48^{\prime} 20.0^{\prime \prime}$ & $96^{\circ} 44^{\prime} 39.1 ”$ \\
\hline $\mathrm{CCO} 44$ & Villa Unión, Sta. M. Tonameca & 135 & $15^{\circ} 48^{\prime} 40.8^{\prime \prime}$ & $96^{\circ} 44^{\prime} 49.4^{\prime \prime}$ \\
\hline $\mathrm{CCO} 45$ & Villa Unión, Sta. M. Tonameca & 134 & $15^{\circ} 48^{\prime} 37.2^{\prime \prime}$ & $96^{\circ} 44^{\prime} 43.6^{\prime \prime}$ \\
\hline $\mathrm{CCO} 46$ & Juana Boquita, Sta. M. Tonameca & 130 & $15^{\circ} 47^{\prime} 50.5^{\prime \prime}$ & $96^{\circ} 44^{\prime} 50.9^{\prime \prime}$ \\
\hline $\mathrm{CCO} 47$ & Juana Boquita, Sta. M. Tonameca & 133 & $15^{\circ} 47^{\prime} 52.6^{\prime \prime}$ & $96^{\circ} 44^{\prime} 57.4 "$ \\
\hline
\end{tabular}


IPGRI (1995).

\section{Statistical analysis}

A random block design with three replications (10 plants per replicate) was used to analyze variance for all agromorphological variables to test differences between populations. The analysis was complemented by applying Tukey's multiple comparisons of means $(p<0.05)$, using Tukey's honestly significant difference (HSD) test. Next, from the matrix of population means, a principal component analysis (PCA) was performed, using variance and covariance, to describe the total phenotypic variation and identify the variables with the highest descriptive value. Next, Ward's hierarchical clustering method was performed, and differences between phenotypic groups were tested using Tukey's analysis of variance and comparison of means $(p<0.05)$. Analyses were performed with SAS statistical package (1999) version 8.0 for Windows.

\section{RESULTS AND DISCUSSION}

Analysis of variance showed significant differences $(p<0.05)$ between populations for all variables tested, except for plant height at 120 DAT (Table 2). The differences between populations show that each farmer maintains a fraction of the total genetic and phenotypic diversity, similar to that reported by Worthington et al. (2012) and Soleri et al. (2013) in relation to genetic differences between common bean populations from the same community. Nonetheless, farmers from neighboring communities call them similar names, like chile costeño (costeño pepper), chile solote (yellow) or chile rojo (red pepper).

Significant differences between populations in plant height at 60 DAT show that during seedling phase, growth varies by population. For example, the population of accession $\mathrm{CCO} 31$ reached $43.1 \mathrm{~cm}$, differing significantly from $\mathrm{CCO} 22$, which reached $77.7 \mathrm{~cm}$ in height. This pattern of differentiation between populations also applies to the number of days to flowering and average fruit length and width. Regarding fruit length and width, at least three phenotypes are present: triangular, total); intermediate, 1.6 to $2.0 \mathrm{~cm}$ wide (15.2\%); and cylindrical or thin, 1.3 to $1.5 \mathrm{~cm}$ wide (Table 3 ). This variability between plant and fruit morphological and physiological traits is of interest to plant breeders because it is a useful raw material for generating and selecting improved material. This observation coincides with the perspective of Jennings \& Cock (1977) regarding genetic and phenotypic diversity of native populations of Capsicum at the centers of origin where diversity is not depleted or where diversity gradually decreases according to differences in the sites, regions, or countries where it was introduced (Rivera et al., 2016).

There were significant differences in agronomic fruit traits between populations. In this sense, ten populations stand out based on measurement of 15 fruits, with yield per plant $>500 \mathrm{~g}$ and consistently inverse relationship between number of fruits per plant and average fruit weight. For example, populations with fewer fruits per plant often have higher fruit weight. The most outstanding populations were $\mathrm{CCO} 34$, $\mathrm{CCO} 35, \mathrm{CCO} 39$, and $\mathrm{CCO} 40$. In terms of yield per plant, according to criteria of 2.1 to $2.2 \mathrm{~cm}$ wide $(17.4 \%$ of the

the breeder, the outstanding populations would be $\mathrm{CCO} 16, \mathrm{CCO} 17, \mathrm{CCO} 19$, $\mathrm{CCO} 21, \mathrm{CCO} 22, \mathrm{CCO} 30, \mathrm{CCO} 34$, $\mathrm{CCO} 39, \mathrm{CCO} 40$, and CCO41 (Table 4). However, according to the traditional pepper producers from Oaxaca, yield per plant is not always the most important selection criterion, as greater weight is given to the adaptability of populations to special agro-ecological niches in their farming plots, fruit flavor and aroma, among other aspects (CastellónMartínez et al., 2012, 2014).

Principal component analysis showed that $84.5 \%$ of the total phenotypic variation was explained by the first two principal components (Figure 1). Variables with the highest descriptive value were as follows: fresh and dry weight of 15 fruits, average fruit weight, number of fruits per plant, and yield per plant. The wide dispersion of populations shown in Figure 1 is an indicator of high agro-morphological variability and phenotypic patterns. Thus, the original populations from the communities of La Oscurana, Villa Unión, and San Juanito are the most dispersed and show high variability. In contrast, populations from Las Pilas are distributed in quadrants II and III (clockwise).The populations in quadrant II yield more per plant and have more

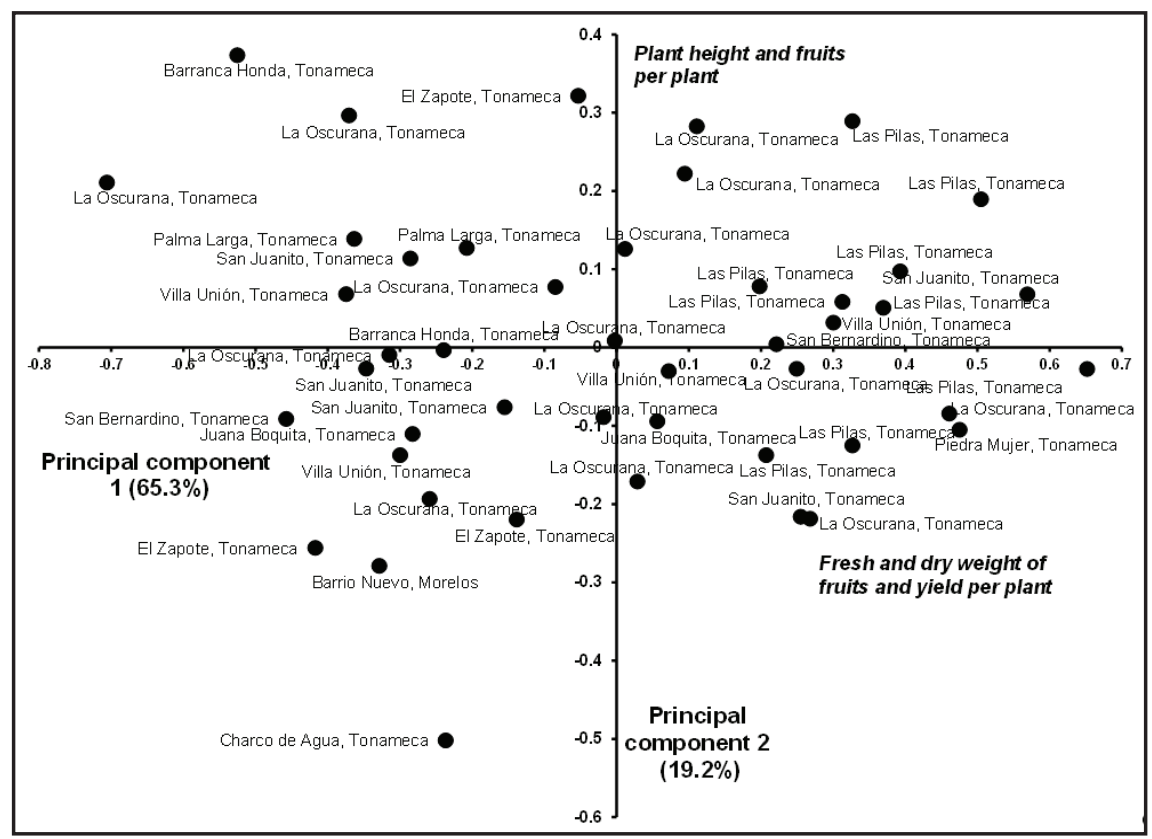

Figure 1. Dispersion of 46 costeño pepper accessions by community of origin in the municipalities of Santa María Tonameca and Santo Domingo de Morelos, Mexico, based on the first two components. Mexico, Instituto Tecnológico del Valle de Oaxaca, 2013. 
fruits and a higher fruit density, among other characteristics. The populations of costeño pepper tested, despite coming from a small geographical region, showed high variability in agromorphological traits (Figure 1).

Cluster analysis identified five different phenotypic groups of costeño pepper with statistical significance (pseudo $\mathrm{F}=23.3, \mathrm{gl}=44, p<0.05$ ). These results confirm the evidence described before; there are significant differences between population groups of costeño pepper within the ecological niche shared by the municipalities of Santo Domingo de Morelos and Santa María Tonameca (Figure 2). Farmers commonly select fruits and seeds to preserve both the fruits they like to use in local gastronomy and those adapted to their agro-ecological niches of production, having influenced to a certain extent intra-territorial differentiation. Kraft et al. (2010) reported the same finding in Aguascalientes, Mexico, for other regional varieties of $C$. апnиum.

The populations of each phenotypic group identified by cluster analysis (Figure 2) are characterized by different agro-morphological traits. To confirm this hypothesis, analysis of variance was used to test differences between groups, finding significant phenotypic differences $(p<0.05)$ for the variables tested, except for the variables plant height at 120 DAT and days to flowering (Table 2). Differentiating between population groups by plant and fruit traits is a common pattern in several morphological characterization studies of C. annuum (Portis et al., 2004; Rivera et al., 2016).

Group I comprised 24 accessions, characterized by having a plant height of 87.3 to $96.6 \mathrm{~cm}$ at 120 DAT, elongated fruits of 5.8 to $6.2 \mathrm{~cm}$, and average fruit weight of 3.6 to $4.7 \mathrm{~g}$. This group includes the original populations from the communities of La Oscurana, El Zapote, Juana Boquita, Villa Unión, San Juanito, and San Bernardino de Santa María Tonameca and the only population from Barrio Nuevo, Santo Domingo de Morelos (Table 5). Group I was subdivided into Group $1 \mathrm{~A}$ and $1 \mathrm{~B}$; the latter stood out with the highest number of fruits per plant, average fruit

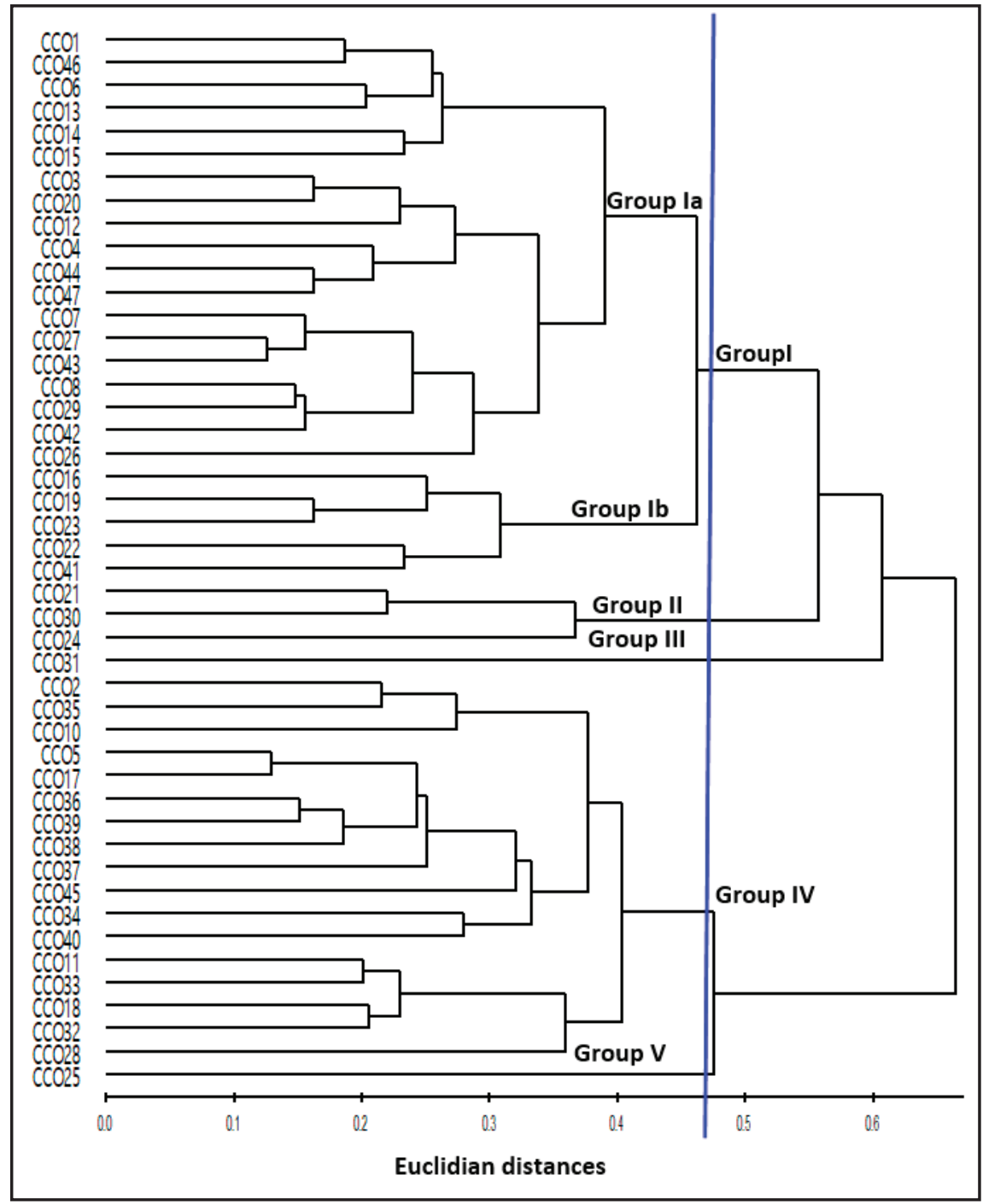

Figure 2. Hierarchical clustering dendrogram of 46 populations of costeño pepper originating in Santa María Tonameca and Santo Domingo de Morelos, Mexico. Mexico, Instituto Tecnológico del Valle de Oaxaca, 2013.

Table 2. Significance of square means from analysis of variance of twelve evaluate traits in forty six populations of costeño pepper. Mexico, Instituto Tecnológico del Valle de Oaxaca, 2013.

\begin{tabular}{lcrc}
\hline Evaluated variables & Square means & Mean & CV (\%) \\
\hline Plant height at 60 dat $^{\dagger}(\mathrm{cm})$ & $700.76^{* *}$ & 63.8 & 26.9 \\
Plant height at 120 dat $(\mathrm{cm})$ & $752.98^{\text {ns }}$ & 89.8 & 28.3 \\
Day to flowering (dat) & $57.12^{* *}$ & 38.0 & 14.0 \\
Fresh weight of 15 fruits $(\mathrm{g})$ & $37.10^{* *}$ & 5.9 & 19.7 \\
Dry weight of 15 fruits $(\mathrm{g})$ & $5.05^{* *}$ & 1.8 & 18.2 \\
Yield per plant $(\mathrm{g})$ & $8.59^{* *}$ & 92.5 & 21.6 \\
No. fruits per plant & $1112.03^{* *}$ & 82.4 & 21.0 \\
Average weight of fruit $(\mathrm{g})$ & $1.71^{* *}$ & 21.0 & 16.4 \\
Fruit length $(\mathrm{cm})$ & $3.12^{* *}$ & 4.4 & 21.5 \\
Fruit width $(\mathrm{cm})$ & $39.92^{* *}$ & 400.7 & 23.6 \\
\hline
\end{tabular}

${ }^{\dagger} \mathrm{ddt}=$ days after transplant; ${ }^{\mathrm{ns}}$ not significant $(p>0.05) ; *$ significant a t $p<0.05 ; * *$ significant at $p<0.01$. 
Table 3. Variability in plant traits, days from transplanting to flowering, and fruit length and width in populations of costeño pepper at Santa Xoxocotlan, Mexico. Mexico, Instituto Tecnológico del Valle de Oaxaca, 2013.

\begin{tabular}{|c|c|c|c|c|c|}
\hline \multirow{2}{*}{ Population } & \multicolumn{2}{|c|}{ Plant height (cm) } & \multirow{2}{*}{$\begin{array}{c}\text { Days to } \\
\text { flowering }\end{array}$} & \multirow{2}{*}{$\begin{array}{l}\text { Fruit width } \\
\text { (cm) }\end{array}$} & \multirow{2}{*}{$\begin{array}{l}\text { Fruit length } \\
\text { (cm) }\end{array}$} \\
\hline & $60 \mathrm{dat}^{\dagger}$ & 120 dat & & & \\
\hline $\mathrm{CCO} 1$ & 59.0 & 94.2 & 41 & 1.8 & 5.8 \\
\hline $\mathrm{CCO} 2$ & 92.6 & 119.8 & 37 & 2.1 & 5.7 \\
\hline $\mathrm{CCO} 3$ & 62.8 & 84.4 & 38 & 1.6 & 4.8 \\
\hline $\mathrm{CCO} 4$ & 61.6 & 78.7 & 35 & 1.3 & 6.4 \\
\hline $\mathrm{CCO} 5$ & 64.8 & 94.6 & 35 & 1.9 & 5.5 \\
\hline $\mathrm{CCO} 6$ & 67.1 & 88.2 & 38 & 1.6 & 6.2 \\
\hline $\mathrm{CCO} 7$ & 71.7 & 102.8 & 36 & 1.6 & 5.5 \\
\hline $\mathrm{CCO} 8$ & 68.7 & 94.3 & 32 & 1.5 & 5.2 \\
\hline CCO10 & 59.4 & 88.6 & 40 & 2.0 & 6.0 \\
\hline CCO11 & 59.7 & 82.8 & 49 & 1.9 & 5.6 \\
\hline $\mathrm{CCO} 12$ & 63.1 & 120.9 & 35 & 1.4 & 5.8 \\
\hline $\mathrm{CCO} 13$ & 57.8 & 82.7 & 33 & 1.6 & 5.9 \\
\hline $\mathrm{CCO} 14$ & 68.7 & 78.0 & 41 & 1.5 & 6.3 \\
\hline $\mathrm{CCO} 15$ & 83.4 & 90.3 & 40 & 1.6 & 7.0 \\
\hline $\mathrm{CCO} 16$ & 60.3 & 86.7 & 37 & 2.1 & 6.1 \\
\hline $\mathrm{CCO} 17$ & 70.7 & 120.0 & 44 & 2.2 & 5.6 \\
\hline $\mathrm{CCO} 18$ & 68.8 & 116.7 & 34 & 1.7 & 6.6 \\
\hline CCO19 & 62.7 & 93.8 & 38 & 1.8 & 5.5 \\
\hline $\mathrm{CCO} 20$ & 54.6 & 86.7 & 38 & 1.6 & 5.3 \\
\hline $\mathrm{CCO} 21$ & 66.2 & 93.0 & 38 & 1.6 & 6.5 \\
\hline $\mathrm{CCO} 22$ & 77.7 & 86.3 & 36 & 2.0 & 6.7 \\
\hline $\mathrm{CCO} 23$ & 72.7 & 132.5 & 38 & 1.7 & 5.9 \\
\hline $\mathrm{CCO} 24$ & 65.4 & 84.0 & 31 & 1.4 & 4.6 \\
\hline $\mathrm{CCO} 25$ & 61.7 & 75.7 & 46 & 2.0 & 5.3 \\
\hline $\mathrm{CCO} 26$ & 52.4 & 70.1 & 40 & 1.5 & 6.8 \\
\hline $\mathrm{CCO} 27$ & 61.3 & 85.5 & 36 & 1.6 & 6.0 \\
\hline $\mathrm{CCO} 28$ & 63.3 & 93.6 & 40 & 1.8 & 5.2 \\
\hline $\mathrm{CCO} 29$ & 55.7 & 79.3 & 45 & 1.6 & 5.5 \\
\hline $\mathrm{CCO} 30$ & 73.2 & 67.5 & 42 & 1.6 & 5.9 \\
\hline CCO31 & 43.1 & 96.4 & 43 & 1.7 & 4.6 \\
\hline $\mathrm{CCO} 32$ & 63.4 & 85.1 & 37 & 1.8 & 6.4 \\
\hline $\mathrm{CCO} 33$ & 46.0 & 89.8 & 40 & 1.8 & 6.0 \\
\hline CCO34 & 63.9 & 102.3 & 44 & 2.1 & 6.7 \\
\hline $\mathrm{CCO} 35$ & 56.9 & 77.8 & 43 & 2.2 & 6.1 \\
\hline CCO36 & 72.7 & -- & 42 & 1.9 & 6.6 \\
\hline $\mathrm{CCO} 37$ & 49.8 & 87.1 & 42 & 2.0 & 6.1 \\
\hline CCO38 & 58.6 & 89.3 & 33 & 1.8 & 6.6 \\
\hline CCO39 & 67.3 & 86.5 & 37 & 1.9 & 6.6 \\
\hline $\mathrm{CCO} 40$ & 61.0 & -- & 40 & 2.2 & 6.4 \\
\hline $\mathrm{CCO} 41$ & 75.4 & 92.3 & 38 & 1.8 & 6.8 \\
\hline $\mathrm{CCO} 42$ & 55.6 & 74.3 & 31 & 1.7 & 4.6 \\
\hline $\mathrm{CCO} 43$ & 69.8 & 84.0 & 27 & 1.6 & 5.4 \\
\hline $\mathrm{CCO} 44$ & 61.0 & 86.5 & 32 & 1.4 & 6.8 \\
\hline $\mathrm{CCO} 45$ & 73.8 & 92.5 & 43 & 2.2 & 5.2 \\
\hline $\mathrm{CCO} 46$ & 63.8 & 81.7 & 35 & 1.9 & 5.6 \\
\hline $\mathrm{CCO} 47$ & 58.9 & 80.0 & 34 & 1.5 & 5.9 \\
\hline DHS-Tukey & 33.1 & 70.0 & 18.3 & 0.19 & 0.7 \\
\hline
\end{tabular}

$\dagger_{\text {dat }}=$ days after transplant; DHS-Tukey $=$ Difference honest significant of Tukey $(p<0.05)$. weight, and yield per plant.

Group II accessions had narrow fruits and high number of fruits per plant (167) but low fruit weight $\left(3.2 \mathrm{~g}\right.$ fruit $\left.^{-1}\right)$, elongated fruits $(5.6 \mathrm{~cm})$, and average yield of $5.175 \mathrm{~g} \mathrm{plant}^{-1}$. This group included medium to low plants $(<87$ $\mathrm{cm})$ at 120 DAT and is characterized by high fruit-set and small fruits. Group III included accession $\mathrm{CCO} 31$, originating from the community of Charco de Agua, Santa María Tonameca. It was characterized by low yields $(82.6 \mathrm{~g}$ plant $\left.^{-1}\right)$, fewer fruits per plant $(<28)$, small fruits ( $4.3 \mathrm{~cm}$ long), and poor vigor (Table 4). These traits may indicate lack of adaptation to greenhouse conditions, as there was poor fruit-set.

Group IV accessions had large fruits that were $6.0 \mathrm{~cm}$ long and $2.0 \mathrm{~cm}$ in diameter and were intermediate in terms of number of fruits (77), but with high fruit density $\left(5.5 \mathrm{~g}\right.$ fruit $\left.{ }^{-1}\right)$. The accessions from Las Pilas, La Oscurana, Piedra Mujer, San Juanito, and Villa Unión were grouped together, and the number of fruits was highest in accessions from Las Pilas. The phenotypic patterns show that populations from Las Pilas differentiate phenotypically from the other populations from Santa María Tonameca, which may be related to handling of seeds, agrosystems, and low seed exchange with their neighboring communities. Group V only includes the accession CCO25 of La Oscurana, Santa María Tonameca, with low plant height at 120 DAT $(75.7 \mathrm{~cm})$ and intermediate yield but with higher fruit density (4.7 $\mathrm{g}$ fruit $^{-1}$ ) and fruits that were triangularelongated shape, 5.3 and $2.0 \mathrm{~cm}$ long and wide. In addition, there was delayed flowering (45 days).

According to Jennings \& Cock (1977), the centers of origin and domestication of cultivated plants have high productivity and genetic diversity because the species continue to evolve under domestication. C. annиит continues to evolve in Mexico (Kraft et al., 2014), particularly near the region of origin of the populations characterized and tested here. This study characterized ten populations of agronomic interest to develop a breeding scheme and to preserve the species in the communities, as these species produce over $0.5 \mathrm{~kg}$ plant $^{-1}$. 
Table 4. Variability in fruit traits between populations of costeño pepper at Santa Cruz Xoxocotlan, Mexico. Mexico, Instituto Tecnológico del Valle de Oaxaca, 2013.

\begin{tabular}{|c|c|c|c|c|c|}
\hline Population & $\begin{array}{c}\text { Fresh weight of } 15 \\
\text { fruit (g) }\end{array}$ & $\begin{array}{l}\text { Dry weight of } 15 \\
\text { fruits (g) }\end{array}$ & $\begin{array}{c}\text { Yield/plant } \\
\text { (g) }\end{array}$ & No. fruits/plant & $\begin{array}{c}\text { Average weight/ } \\
\text { fruit (g) }\end{array}$ \\
\hline $\mathrm{CCO} 1$ & 83.7 & 17.2 & 288.7 & 66.4 & 4.7 \\
\hline $\mathrm{CCO} 2$ & 110.7 & 27.4 & 277.9 & 49.5 & 5.6 \\
\hline $\mathrm{CCO} 3$ & 56.0 & 13.7 & 223.4 & 65.3 & 3.2 \\
\hline $\mathrm{CCO} 4$ & 53.3 & 12.0 & 305.5 & 98.1 & 3.1 \\
\hline $\mathrm{CCO} 5$ & 95.3 & 23.0 & 441.8 & 83.0 & 5.4 \\
\hline $\mathrm{CCO} 6$ & 73.7 & 17.6 & 306.4 & 84.5 & 3.6 \\
\hline $\mathrm{CCO} 7$ & 68.0 & 15.8 & 455.1 & 120.9 & 3.9 \\
\hline $\mathrm{CCO} 8$ & 63.7 & 12.4 & 380.7 & 108.0 & 3.5 \\
\hline $\mathrm{CCO} 10$ & 121.0 & 37.7 & 432.2 & 79.3 & 5.5 \\
\hline CCO11 & 93.0 & 26.5 & 211.5 & 41.9 & 5.0 \\
\hline $\mathrm{CCO} 12$ & 54.7 & 9.4 & 199.5 & 64.6 & 3.2 \\
\hline $\mathrm{CCO} 13$ & 71.3 & 14.7 & 260.7 & 66.8 & 3.9 \\
\hline $\mathrm{CCO} 14$ & 89.3 & 21.3 & 360.4 & 91.9 & 3.9 \\
\hline $\mathrm{CCO} 15$ & 81.0 & 16.1 & 318.5 & 72.4 & 4.4 \\
\hline $\mathrm{CCO} 16$ & 84.3 & 21.1 & 699.7 & 127.0 & 5.4 \\
\hline $\mathrm{CCO} 17$ & 96.0 & 21.4 & 403.4 & 77.6 & 5.0 \\
\hline $\mathrm{CCO} 18$ & 93.0 & 31.8 & 206.6 & 42.8 & 4.7 \\
\hline CCO19 & 85.7 & 22.2 & 540.8 & 118.1 & 4.4 \\
\hline $\mathrm{CCO} 20$ & 61.3 & 15.4 & 270.9 & 69.4 & 3.9 \\
\hline $\mathrm{CCO} 21$ & 62.7 & 13.8 & 599.9 & 153.8 & 3.9 \\
\hline $\mathrm{CCO} 22$ & 94.3 & 28.7 & 573.3 & 134.1 & 4.3 \\
\hline $\mathrm{CCO} 23$ & 77.0 & 17.9 & 506.8 & 109.9 & 4.6 \\
\hline $\mathrm{CCO} 24$ & 47.3 & 10.4 & 382.4 & 167.6 & 2.4 \\
\hline $\mathrm{CCO} 25$ & 105.3 & 42.1 & 343.8 & 64.6 & 4.7 \\
\hline $\mathrm{CCO} 26$ & 73.7 & 19.2 & 442.4 & 121.5 & 3.6 \\
\hline $\mathrm{CCO} 27$ & 60.7 & 17.1 & 430.0 & 124.9 & 3.4 \\
\hline $\mathrm{CCO} 28$ & 88.0 & 29.3 & 358.6 & 91.0 & 4.2 \\
\hline $\mathrm{CCO} 29$ & 71.7 & 16.0 & 355.9 & 105.8 & 3.2 \\
\hline $\mathrm{CCO} 30$ & 63.0 & 14.9 & 596.3 & 182.4 & 3.3 \\
\hline $\mathrm{CCO} 31$ & 61.1 & 16.3 & 82.6 & 27.6 & 3.0 \\
\hline $\mathrm{CCO} 32$ & 100.0 & 28.7 & 301.9 & 59.9 & 5.2 \\
\hline $\mathrm{CCO} 33$ & 93.0 & 22.8 & 353.2 & 64.1 & 5.5 \\
\hline $\mathrm{CCO} 34$ & 117.3 & 26.6 & 584.0 & 96.0 & 6.1 \\
\hline $\mathrm{CCO} 35$ & 118.8 & 33.6 & 346.5 & 55.5 & 6.5 \\
\hline $\mathrm{CCO} 36$ & 102.3 & 25.3 & 427.4 & 78.9 & 5.1 \\
\hline $\mathrm{CCO} 37$ & 101.7 & 31.7 & 455.4 & 81.9 & 5.5 \\
\hline $\mathrm{CCO} 38$ & 96.7 & 21.6 & 498.8 & 94.7 & 5.4 \\
\hline CCO39 & 109.3 & 27.1 & 505.1 & 89.2 & 5.8 \\
\hline $\mathrm{CCO} 40$ & 101.0 & 23.6 & 809.6 & 126.8 & 6.3 \\
\hline $\mathrm{CCO} 41$ & 80.0 & 24.4 & 671.2 & 143.8 & 4.7 \\
\hline $\mathrm{CCO} 42$ & 66.0 & 14.9 & 389 & 115.3 & 3.3 \\
\hline $\mathrm{CCO} 43$ & 59.0 & 17.4 & 414.4 & 120.7 & 3.3 \\
\hline $\mathrm{CCO} 44$ & 64.0 & 12.8 & 288.2 & 84.6 & 3.4 \\
\hline $\mathrm{CCO} 45$ & 94.0 & 21.5 & 466.3 & 73.9 & 5.7 \\
\hline $\mathrm{CCO} 46$ & 85.0 & 18.9 & 305.3 & 68.9 & 4.4 \\
\hline $\mathrm{CCO} 47$ & 63.7 & 13.0 & 343.7 & 92.1 & 3.5 \\
\hline DHS-Tukey & 58.92 & 2.5 & 15.5 & 6.8 & 3.2 \\
\hline
\end{tabular}


Table 5. Mean descriptive values of agro-morphological traits of the phenotypic groups of costeño pepper at Santa Cruz Xoxocotlan, Mexico. Mexico, Instituto Tecnológico del Valle de Oaxaca, 2013.

\begin{tabular}{lcccccc}
\hline \multirow{2}{*}{ Evaluated variables } & \multicolumn{7}{c}{ Groups } \\
\cline { 2 - 7 } & Ia (19) & Ib (5) & II (3) & III (1) & IV (12) & V(6) \\
\hline Plant height at 60 dat $(\mathrm{cm})$ & $63.0 \mathrm{ab} \dagger$ & $69.3 \mathrm{a}$ & $66.9 \mathrm{a}$ & $43.1 \mathrm{~b}$ & $64.0 \mathrm{ab}$ & $61.7 \mathrm{ab}$ \\
Plant height at 120 dat $(\mathrm{cm})$ & $87.3 \mathrm{a}$ & $96.6 \mathrm{a}$ & $86.2 \mathrm{a}$ & $96.4 \mathrm{a}$ & $93.8 \mathrm{a}$ & $75.7 \mathrm{a}$ \\
Day to flowering (dat) & $36.2 \mathrm{a}$ & $37.5 \mathrm{a}$ & $36.3 \mathrm{a}$ & $42.5 \mathrm{a}$ & $40.1 \mathrm{a}$ & $45.7 \mathrm{a}$ \\
Fresh weight of 15 fruits (g) & $68.4 \mathrm{~b}$ & $84.3 \mathrm{ab}$ & $57.0 \mathrm{~b}$ & $61.0 \mathrm{~b}$ & $102.2 \mathrm{a}$ & $105.3 \mathrm{a}$ \\
Dry weight of 15 fruits (g) & $15.5 \mathrm{~cd}$ & $22.9 \mathrm{bc}$ & $12.8 \mathrm{~d}$ & $16.3 \mathrm{bcd}$ & $27.0 \mathrm{~b}$ & $42.1 \mathrm{a}$ \\
Yield per plant (g) & $333.6 \mathrm{a}$ & $598.4 \mathrm{a}$ & $517.5 \mathrm{a}$ & $82.6 \mathrm{~b}$ & $422.0 \mathrm{a}$ & $343.8 \mathrm{a}$ \\
No. fruits per plant & $91.7 \mathrm{bc}$ & $126.6 \mathrm{ab}$ & $166.1 \mathrm{a}$ & $27.6 \mathrm{~d}$ & $76.6 \mathrm{bc}$ & $64.6 \mathrm{~cd}$ \\
Average weight of fruit (g) & $3.6 \mathrm{bcd}$ & $4.7 \mathrm{abc}$ & $3.2 \mathrm{~cd}$ & $3.0 \mathrm{~d}$ & $5.5 \mathrm{a}$ & $4.7 \mathrm{ab}$ \\
Fruit length $(\mathrm{cm})$ & $5.8 \mathrm{a}$ & $6.2 \mathrm{a}$ & $5.6 \mathrm{a}$ & $4.3 \mathrm{~b}$ & $6.0 \mathrm{a}$ & $5.3 \mathrm{ab}$ \\
Fruit width $(\mathrm{cm})$ & $1.6 \mathrm{bc}$ & $1.9 \mathrm{ab}$ & $1.5 \mathrm{c}$ & $1.7 \mathrm{abc}$ & $2.0 \mathrm{a}$ & $2.0 \mathrm{a}$ \\
\hline
\end{tabular}

${ }^{\dagger} \mathrm{ddt}=$ days after transplant; ${ }^{\dagger}$ in row, means with same letter are not different significantly (Tukey’s test, $p<0.05$ ).

\section{REFERENCES}

AGUILAR-MELENDEZ, A; MORRELL, PL; ROOSE, ML; KIM, SCH. 2009. Genetic diversity and structure in semiwild and domesticated chiles (Capsicum annuиm; Solanaceae) from Mexico. American Journal of Botany 96: 1190-1202.

AGUILAR-RINCÓN, VH; CORONA-TORRES, T; LÓPEZ-LÓPEZ, P; LATOURNERIEMORENO, L; RAMÍREZ-MERAZ, M; VILLALÓN-MENDOZA, H; AGUILARCASTILLO, JA. 2010. Los chiles de México y su distribución. SINAREFI, Colegio de Postgraduados. México, Texcoco: INIFAP, IT-Conkal, UNAL y UAN. 114p.

BOEGE, SE. 2008. El patrimonio biocultural de los pueblos indígenas de México. Instituto Nacional de Antropología e Historia: Comisión Nacional para el Desarrollo de los Pueblos Indígenas. México, DF. 344p.

CASTELLÓN-MARTÍNEZ, E; CARRILLORODRÍGUEZ, JC; CHÁVEZ-SERVIA, JL; VERA GUZMÁN, AM. 2014. Variación fenotípica de morfotipos de chile (Caspsicum annuиm L.) nativo de Oaxaca, México. Revista Internacional de Botánica Experimental 83: 225-236.

CASTELLÓN-MARTÍNEZ, E; CHÁVEZSERVIA, JL; CARRILLO-RODRÍGUEZ, JC;VERA-GUZMÁN, AM. 2012. Preferencias de consumo de chiles (Capsicum annuum $\mathrm{L}$.) nativos en los Valles Centrales de Oaxaca. Revista Fitotecnia Mexicana 35: 27-35 (numero especial, 5).

CAZARES, E; RAMÍREZ, P; CASTILLO, F; SOTO, RM; RODRÍGUEZ, MT; CHÁVEZ, JL. 2005. Capsaicinoides y preferencia de uso en diferentes morfotipos de Chile (Capsicum annuum L.) del centro-oriente de Yucatán. Agrociencia 39: 627-638.

INIFAP (Instituto Nacional de Investigaciones, Forestales Agrícolas y Pecuarias). 2012. Red de Estaciones Agroclimatológicas. SAGARPA, México D.F. Available at http://clima.inifap.gob.mx/redinifap/est. aspx?est=36361. Accessed August 2, 2015.

JENNINGS, PR; COCK, JH. 1977. Center of origin of crops and their productivity. Economic Botany 31: 51-54.

KADRI, M; ESIYOK, D; TURHAN, K. 2009. Patterns of phenotypic variation in a germplasm collection of pepper (Capsicum annuиm L.) from Turkey. Spanish Journal of Agricultural Research 7: 83-95.

KRAFT, KH; BROWN, CH; NABHAN, GP, LUEDELING, E; LUNA-RUIZ, JJ; D'EECKENBRUGGE, GC; HIJMANS, QJ; GEPTS, P. 2014. Multiple lines of evidence for the origin of domesticated chili pepper, Capsicum annuum, in Mexico. Proceeding of National,Academy science of USA 111: 6165-6170

KRAFT, KH; LUNA-RUIZ, JJ; GEPTS, P. 2010. Different seed selection and conservation practices for fresh market and dried chili farmers in Aguascalientes, Mexico. Economic Botany 64: 319-328.

NAREZ-JIMÉNEZ, CA; CRUZ-LÁZARO, E; GÓMEZ-VÁZQUEZ, A; CASTAÑÓNNÁJERA, G; CRUZ-HERNÁNDEZ, A; MÁRQUEZ-QUIROZ, C. 2014. La diversidad morfológica in situ de chiles silvestres (Capsicum spp.) de Tabasco, México. Revista Fitotecnia Mexicana 37: 209-215.

OCCHIUTO, PN; PERALTA, IE; ASPRELLI, P D; GALMARINI, CR. 2014. Characterization of Capsicum germplasm collected in Northwestern Argentina based on morphological and quality traits. Agriscientia 31: 63-73.

OVANDO, CME. 2007. Producción de chile costeño con agribón y fertirriego en la costa de Oaxaca. Revista Agroproduce 2007: 20-21.

PORTIS, E; ACQUADRO, A; COMINO, C; LANTERIS. 2004. Effect of farmers' seed selection on genetic variation of a landraces population of pepper (Capsicum annuит L.), grown in North-West Italy. Genetic Resources and Crop Evolution 51: 581-290.

RÊGO, ER; RÊGO, MM; CRUZ, CD; FINGER,
FL; CASALI, VWD. 2011. Phenotypic diversity, correlation and importance of variables for fruit quality and yield traits in Brazilian peppers (Capsicum baccatum). Genetic Resources and Crop Evolution 58: 909-918.

RIVERA, A, MONTEAGUDO, AB; IGARTUA, E; TABOADA, A; GARCÍA-ULLOA, A; POMAR, F; RIVEIRO-LEIRA, M; SILVAR, C. 2016. Assessing genetic and phenotypic diversity in pepper (Capsicum annuит L.) landraces from North-West Spain. Scientia Horticulturae 203: 1-11.

SAS. 1999. SAS ${ }^{\circledR}$ Procedures Guide, Version 8. USA: SAS Institute Inc. 1643p.

SIAP (Sistema de Información Agroalimentaria y Pesquera). 2015. Anuario Estadístico de la Producción Agrícolas 2015. SIAP-SAGARPA, México, D.F. Available at http://www.siap. gob.mx/cierre-de-la-produccion-agricola-porcultivo/. Accessed April, 2018.

SILVA, AR; RÊGO, ER; CECON, PR. 2011. Tamanho de amostra para caracterizacão morfológica de frutos de pimenteira. Horticultura Brasileira 28: 125-129.

SOLERI, D; WORTHINGTON, M; ARAGÓNCUEVAS, F; STEVEN, E. SMITH, SE; GEPTS, P. 2013. Farmers' varietal identification in a reference sample of local Phaseolus species in the Sierra Juárez, Oaxaca, México. Economic Botany 67: 283-298.

VAN ZONNEVELD, M; RAMIREZ, M; WILLIAMS, DE; PETZ, M; MECKELMANN, S; AVILA, T; BEJARANO, C; RIOS, LL; PEÑA, K; JÄGER, M; LIBREROS, D; AMAYA, K; SCHELDEMA, X. 2015. Screening genetic resources of Capsicum peppers in their primary center of diversity in Bolivia and Peru. Plos One 10: 9.

VOTAVA, JE; BARAL, BJ; BOSLAND, WP. 2005. Genetic diversity of chile (Capsicum annuиm var. annuиm L.) landraces from Northern New Mexico, Colorado and Mexico. Economic Botany 59: 8-17.

WORTHINGTON, M; SOLERI, D; ARAGÓNCUEVAS, F; GEPTS, P. 2012. Genetic 
composition and spatial distribution of farmer-managed Phaseolus bean plantings: an example from a village in Oaxaca, Mexico. Crop Science 52: 1721-1735.
ZHANI, K; HAMDI, W; SEDRAOUI, S; FENDRI, R; LAJIMI, O; HANNACHI, CH. 2015. A comparative study of morphological characterization of Tunisian accessions of chili pepper (Capsicum frutescens L.). International Research Journal of Engineering and Technology 2: 87-94. 